\title{
ANALISIS PERMINTAAN DAN PERSAINGAN MINYAK KELAPA (CRUDE COCONUT OIL) INDONESIA DI PASAR INTERNASIONAL
}

\author{
Rizki Puspita Dewanti ${ }^{1}$, Harianto ${ }^{2}$, dan Rita Nurmalina ${ }^{3}$ \\ 1)Program Magister Sains Agribisnis, Sekolah Pascasarjana, Institut Pertanian Bogor \\ 2,3)Departemen Agribisnis, Fakultas Ekonomi dan Manajemen, Institut Pertanian Bogor \\ Jl. Kamper Kampus IPB Dramaga Bogor, Indonesia \\ e-mail : 1)rizkipuspitadewanti@gmail.com \\ (Diterima 28 Mei 2019/Disetujui 25 Juni 2019)
}

\begin{abstract}
As the world's largest coconut producer, Indonesia has the opportunity to become the main exporter of processed coconut products. Crude coconut oil (CCO) is one of the leading processed coconut products which is currently increasing in demand. In the export market of crude coconut oil, Indonesia deals with intense competition with other crude coconut oil exporters. The objective of this study was to analyze the factors that influence the import demand of Indonesian crude coconut oil and competition between Indonesian crude coconut oil with other crude coconut oil exporters in the international market. The analytical method used was the Almost Ideal Demand System (AIDS). The results showed that the factors that influence import demand of Indonesian crude coconut oil in the international market were various and Indonesian crude coconut oil could compete with crude coconut oil from Philippine in the US and German markets. The competition was indicated by the positive cross elasticity value (substitution). The decreasing price of crude coconut oil of Philippine will reduce the market share of Indonesian crude coconut oil. Therefore, Indonesia needs to improve its marketing strategy and increase crude coconut oil production to increase Indonesian crude coconut oil exports.
\end{abstract}

Keywords: AIDS, competition, crude coconut oil, import demand

\begin{abstract}
ABSTRAK
Sebagai negara produsen terbesar kelapa dunia, memberikan kesempatan Indonesia untuk menjadi eksportir utama produk olahan kelapa. Minyak kelapa merupakan salah satu produk unggulan olahan kelapa yang saat ini permintaanya semakin meningkat. Dalam ekspor minyak kelapa ke pasar internasional, Indonesia mendapat persaingan yang ketat dengan eksportir minyak kelapa lainnya. Tujuan penelitian ini adalah untuk menganalisis tingkat persaingan minyak kelapa Indonesia dengan eksportir minyak kelapa lainnya di pasar internasional. Metode analisis yang digunakan adalah Almost Ideal Demand System (AIDS). Hasil penelitian menunjukkan bahwa faktor-faktor yang memengaruhi permintaan minyak kelapa Indonesia di pasar internasional berbeda-bedad dan minyak kelapa Indonesia bersaing dengan minyak kelapa Filipina di pasar Amerika Serikat dan Jerman. Hal ini dibuktikan dengan nilai elastisitas harga silang yang positif (substitusi). Penurunan harga minyak kelapa Filipina, maka akan menurunkan pangsa pasar Indonesia. Oleh sebab itu, Indonesia perlu meningkatkan produksi dan stategi pemasaran minyak kelapa untuk meningkatkan ekspor minyak kelapa Indonesia di pasar internasional.
\end{abstract}

Kata kunci: AIDS, persaingan, minyak kelapa, permintaan impor

\section{PENDAHULUAN}

Pada tahun 2017, Indonesia menempati urutan pertama sebagai produsen kelapa terbesar di dunia. Produksi kelapa Indonesia mencapai 18,9 juta ton, kemudian diikuti oleh Filipina dan India dengan volume produksi masing-masing sebesar 14,05 juta ton dan 11,5 juta ton (FAOSTAT 2017). Allelorung et al. (2005) menyatakan bahwa peluang pengem- 
bangan agribisnis kelapa di Indonesia dengan produk bernilai ekonomi tinggi masih sangat besar, tetapi saat ini industri pengolahan kelapa di Indonesia masih didominasi oleh produk setengah jadi berupa kopra dan minyak kelapa (Aulia, 2017). Diantara kopra dan minyak kelapa, minyak kelapa memiliki nilai ekonomi yang lebih tinggi. Hal ini dikarenakan pengolahan minyak kelapa terbukti dapat meningkatkan pendapatan pelaku agribisnis dibandingkan dengan hanya menjual olahan kelapa dalam bentuk kopra (Arimbawa dan Zani, 2013; Setyawan dan Purwanti, 2016). Selain itu, minyak kelapa juga banyak dibutuhkan diberbagai bidang industri, seperti industri makanan, kesehatan, dan kosmetik. Adanya peningkatan kebutuhan minyak kelapa diberbagai bidang industri tersebut menjadi peluang besar bagi Indonesia untuk memperdagangkan produk minyak kelapa di pasar internasional, terlebih permintaan minyak kelapa dunia saat ini juga semakin meningkat. USDA (2016) dalam sebuah laporannya menyatakan bahwa perdagangan minyak kelapa mentah dunia akan semakin meningkat sejalan dengan peningkatan produksi dari Filipina dan Vietnam.

Permintaan minyak kelapa dunia saat ini didominasi oleh negara-negara yang mengembangkan produk turunan minyak kelapa, seperti Belanda, Amerika Serikat, Jerman, Italia, Perancis, Cina, Spanyol, Meksiko, dan Inggris. Sedangkan produksi utama minyak kelapa berasal dari negara yang tergabung dalam Asia Pasific Coconut Community (APCC), yang terdiri dari India, Indonesia, Federasi Mikronesia, Fiji, Kiribati, Malaysia, Kepulauan Marshall, Papua Nugini, Filipina, Samoa, Solomon, Sri Lanka, Thailand, Tonga, Vanuatu, dan Vietnam.

Sampai saat ini dominasi ekspor minyak kelapa dunia dilakukan oleh negara yang tergabung dalam APCC yaitu sebanyak 94 persen ekspor minyak kelapa dunia didominasi oleh negara-negara APCC dan sisanya diekspor oleh negara lain diluar APCC (UN Comtrade, 2016 dalam Anajohn, 2018). Sedangkan impor minyak kelapa didominasi oleh Amerika Serikat, Belanda, dan Jerman yang menempati posisi tiga besar pengimpor minyak kelapa terbesar dunia. Di tahun 2015, Amerika Serikat, Belanda, dan Jerman menempati urutan pertama hingga ketiga dari 10 negara pengimpor minyak kelapa terbesar di dunia, dengan masing-masing share impor sebesar 33,18 persen, 15,66 persen dan 14,05 persen, diikuti oleh Malaysia sebesar 12,09 persen, dan Cina sebesar 8,74 persen (Gambar $1)$.

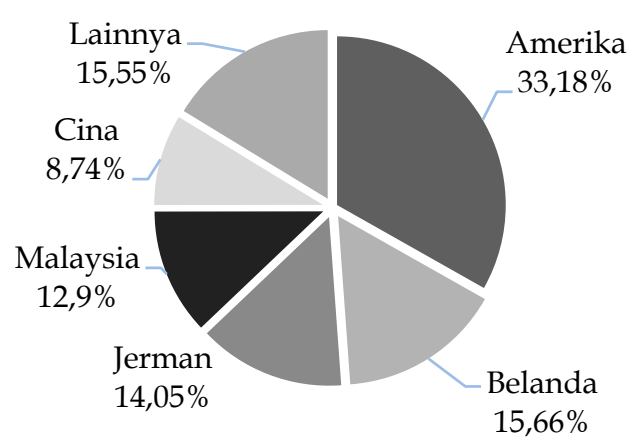

\section{Gambar 1. Presentase Impor Negara Importir Minyak Kelapa Tahun 2015 Sumber : FAOSTAT (2018)}

Filipina, Indonesia, dan Malaysia merupakan negara APCC yang memiliki share tertinggi dalam ekspor minyak kelapa dunia. Filipina menempati urutan pertama sebagai pengekspor minyak kelapa terbesar di dunia, yang kemudian diikuti oleh Indonesia dan Malaysia dengan pangsa ekspor masingmasing sebesar 41,55 persen, 35,31 persen, dan 8,59 persen (Gambar 2).

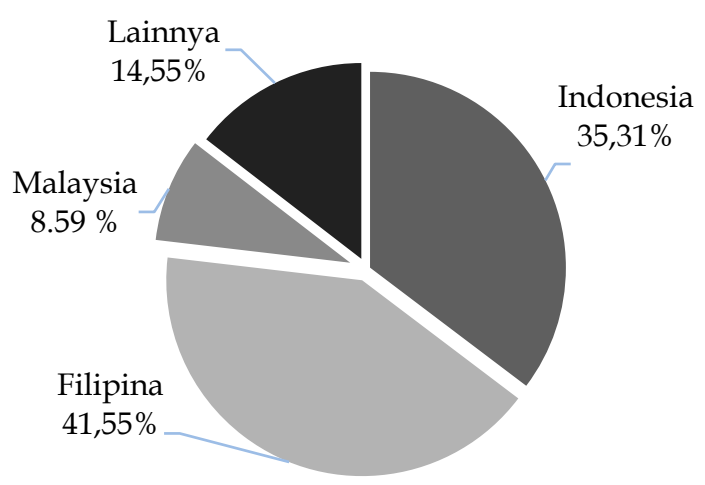

Gambar 2. Presentase Ekspor Minyak Kelapa Pada Negara APCC Tahun 2016 Sumber : UN Comtrade (2018) 
Saat ini pertumbuhan ekspor minyak kelapa Indonesia masih tertinggal jika dibandingkan dengan negara pesaingnya yaitu Filipina. Selama periode tahun 2010 hingga 2017, beberapa kali ekspor minyak kelapa Indonesia mengalami penurunan yang signifikan. Diantaranya tahun 2013 dan tahun 2017. Di tahun 2013, pangsa ekspor minyak kelapa Indonesia turun hingga 44,34 persen dengan nilai ekspor sebesar US\$ 527,5, sementara ekspor minyak kelapa Filipina dan Malaysia cenderung stabil di tahun tersebut. Di tahun 2017, ekspor minyak kelapa Indonesia kembali menurun hingga 47,87 persen, sehingga pangsa ekspor minyak kelapa Indonesia menjadi 21,10 persen. Sedangkan pangsa ekspor minyak kelapa Filipina semakin meningkat menjadi 63,40 persen dan Malaysia sedikit mengalami penurunan menjadi 6,8 persen (Gambar 3).

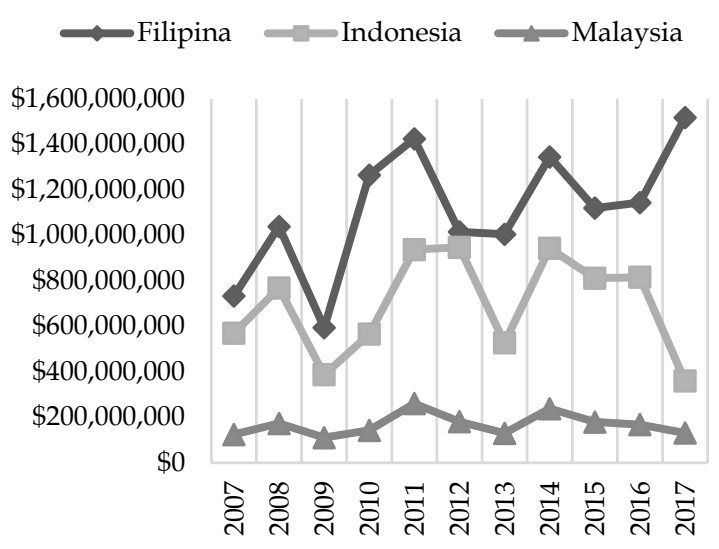

\section{Gambar 3. Perkembangan Nilai Impor \\ Minyak Kelapa Filipina, Indonesia, dan Malaysia Tahun 2007-2018 \\ Sumber : UN Comtrade (2018)}

Adanya fluktuasi ekspor minyak kelapa diantara Filipina, Indonesia, dan Malaysia pada Gambar 3 tersebut, mengindikasikan bahwa terdapat persaingan yang ketat diantara ketiga negara pengekspor minyak kelapa tersebut. Terlebih permintaan minyak kelapa dunia saat ini juga semakin meningkat. Oleh sebab itu, kondisi ini mendorong negaranegara eksportir minyak kelapa untuk bersaing dalam menguasai posisi utama sebagai eksportir minyak kelapa di pasar inter- nasional. Dengan demikian, penelitian ini bertujuan untuk menganalisis faktor-faktor yang memengaruhi permintaan minyak kelapa Indonesia di pasar internasional (Amerika Serikat, Belanda, dan Jerman) serta menganalisis tingkat persaingan minyak kelapa Indonesia dengan Filipina di pasar internasional (Amerika Serikat, Belanda, dan Jerman).

\section{METODE}

Data yang digunakan dalam penelitian ini berupa data sekunder time series selama 26 tahun yaitu tahun 1992 sampai 2017. Negara yang menjadi objek penelitian ini adalah Amerika Serikat, Belanda, dan Jerman sebagai negara pengimpor minyak kelapa terbesar didunia serta Indonesia dan Filipina sebagai negara pengekspor minyak kelapa yang memiliki pangsa ekspor minyak kelapa tertinggi di dunia. Data perdagangan yang digunakan menggunakan data impor minyak kelapa (CCO) dengan kode SITC Rev. 24243 (coconut copra oil). Adapun harga yang digunakan dihitung dengan membagi nilai impor dengan volume impor pada masingmasing negara pengimpor (Amerika Serikat, Belanda, dan Jerman) dari impor di masingmasing negara sumber impor (Indonesia, Filipina, dan Malaysia).

Data penelitian dianalisis dengan menggunakan pendekatan ekonometrika dengan model Almost Ideal Demand System (AIDS) yang pertama kali diperkenalkan oleh Deaton dan Muelbauer (1980) yang digunakan untuk menganalisis sistem permintaan konsumen. Salah satu kelebihan model AIDS ini adalah memberikan kemampuan pendekatan orde pertama untuk sistem permintaan. Selain itu, model AIDS juga dapat mengakomodasi hambatan-hambatan dan konsisten terhadap teori permintaan seperti aditivitas, homogenitas, dan simetri (Kahar, 2010). Dalam perkembangannya, model AIDS ini dapat dipinjam untuk mengestimasi persaingan negara eksportir dalam perdagangan internasional, seperti penelitian yang telah dilaku- 
kan oleh Jung dan Koo (2000), Chang dan Nguyen (2002), Wan et al. (2010), Jiumpanyarach (2011), Rifin (2013), Jamil (2015), Destiarni (2016), Rachmi et al. (2017), dan Maemunah (2018). Adapun persamaan model AIDS dalam penelitian ini sebagai berikut :

$$
\begin{aligned}
\mathrm{W}_{\text {Ind }}= & \alpha_{1}+\gamma_{1} \ln \mathrm{P}_{\text {Ind }}+\gamma_{2} \ln \mathrm{P}_{\text {Phil }}+\gamma_{3} \ln \mathrm{P}_{\text {Mal }}+ \\
& \gamma_{4} \ln \mathrm{P}_{\text {Row }}+\beta_{1} \ln \left(\frac{x}{p *}\right)+\theta_{1} \ln \mathrm{ER}_{\mathrm{i}, \text { ind }}+\lambda_{1} \\
& \ln \mathrm{POP}_{\mathrm{i}}+\sigma_{1} \mathrm{GDP}_{\mathrm{i}}+\phi_{1} \ln \mathrm{PS}_{\mathrm{i}}+\epsilon_{1} \ln \\
& \mathrm{PO}+£_{1} \mathrm{D} \\
\mathrm{W}_{\text {Phil }}= & \alpha_{2}+\gamma_{5} \ln \mathrm{P}_{\text {Ind }}+\gamma_{6} \ln \mathrm{P}_{\text {Phil }}+\gamma_{7} \ln \mathrm{P}_{\text {Mal }}+ \\
& \gamma_{9} \ln \mathrm{P}_{\text {Row }}+\beta_{2} \ln \left(\frac{x}{p *}\right)+\theta_{2} \ln \mathrm{ER}_{\mathrm{i}, \text { phil }}+ \\
& \lambda_{2} \ln \mathrm{POP}_{\mathrm{i}}+\sigma_{2} \mathrm{GDP}_{\mathrm{i}}+\phi_{2} \ln \mathrm{PS}_{\mathrm{i}}+€_{2} \ln \\
& \mathrm{PO}+£_{2} \mathrm{D}
\end{aligned}
$$

Keterangan :

$\alpha, \gamma, \beta, \theta, \lambda, \sigma, \varphi, €, £=$ Parameter regresi

$\mathrm{i}=$ Amerika Serikat, Belanda, Jerman

$\mathrm{W}_{\text {ind }}=$ Share ekspor Indonesia

$\mathrm{w}_{\text {phil }}=$ Share ekspor Filipina

$\mathrm{x} / \mathrm{p}^{*}=$ Total nilai impor yang dipengaruhi indeks harga stone

Pind $_{\mathrm{i}}=$ Harga minyak kelapa Indonesia (US\$/ton) di negara pengimpor

Pphil $_{\mathrm{i}}=$ Harga minyak kelapa Filipina (US\$/ton) di negara pengimpor

Prow $_{\mathrm{i}}=$ Harga minyak kelapa rest of world (US\$/ton) di negara pengimpor

$\mathrm{ER}_{\mathrm{i}}=$ Nilai tukar riil $(\mathrm{US} \$ / \mathrm{Rp})$

$\mathrm{POP}_{\mathrm{i}}=$ Populasi negara pengimpor (jiwa)

$\mathrm{GDP}_{\mathrm{i}}=$ Pertumbuhan GDP negara Pengimpor (\%)

$\mathrm{PS}_{\mathrm{i}} \quad=$ Harga barang substitusi (US\$/ton)

$\mathrm{PO}=$ Harga minyak bumi (US\$/bbl)

$\mathrm{D}=$ Dummy krisis ekonomi, setelah tahun $2008=1$, sebelum tahun 2008 $=0$

Dalam penelitian ini, digunakan palm kernel oil sebagai barang substitusi dari minyak kelapa (crude coconut oil). Pemilihan barang substitusi tersebut dikarenakan keduanya memiliki senyawa kimia yang sama atau disebut dengan lauric acid. Oleh karena itu, diduga palm kernel oil merupakan barang pengganti dari crude coconut oil di negara pengimpor.

Hasil estimasi model AIDS juga digunakan untuk menjawab faktor-faktor yang memengaruhi permintaan minyak kelapa Indonesia di pasar Amerika Serikat, Belanda, dan Jerman. Variabel yang berpengaruh terhadap permintaan impor minyak kelapa Indonesia dapat dilihat dari signifikansi masing-masing variabel dan untuk melihat seberapa besar pengaruh variabel dilihat berdasarkan nilai koefisien dari hasil estimasi model. Kemudian dari parameter yang diestimasi dapat ditentukan pula nilai elastisitas dari masing-masing negara sumber impor. Nilai elastisitas dihitung dengan tujuan untuk melihat gambaran persaingan yang terjadi diantara negara sumber impor. Nilai elastisitas yang dihitung berupa (1) elastisitas harga sendiri, (2) elastisitas harga silang, dan (3) elastisitas pengeluaran, yang dirumuskan sebagai berikut :

Elastisitas harga sendiri :

$$
\boldsymbol{e}_{i j}=-1+\frac{\boldsymbol{y}_{i j}}{\boldsymbol{w}_{\boldsymbol{i}}}-\boldsymbol{\beta}_{i}\left(\frac{w_{\boldsymbol{j}}}{w_{i}}\right)
$$

Elastisitas harga silang :

$$
\boldsymbol{e}_{i j}=\frac{\boldsymbol{y}_{i j}}{\boldsymbol{w}_{\boldsymbol{i}}}-\boldsymbol{\beta}_{\boldsymbol{i}}\left(\frac{w_{j}}{w_{i}}\right) ; \mathrm{i} \neq \mathrm{j}
$$

Elastisitas pengeluaran :

$$
\eta \mathrm{i}=1+\frac{\beta_{i}}{w_{i}}
$$

\section{HASIL DAN PEMBAHASAN}

\section{PANGSA PASAR NEGARA SUMBER IMPOR MINYAK KELAPA DI PASAR INTERNASIONAL}

Permintaan impor minyak kelapa dunia didominasi oleh negara-negara yang mengembangkan produk turunan minyak kelapa seperti Amerika Serikat, Belanda, dan Jerman. Ketiga negara tersebut merupakan tiga besar pengimpor minyak kelapa di pasar dunia. Menjadi negara produsen terbesar minyak kelapa dunia, seharusnya Indonesia mampu mendominasi ekspor minyak kelapa di pasar internasional, namun eksportir terbesar minyak kelapa dunia sampai saat ini didominasi oleh Filipina. Dengan demikian, 
Indonesia dan Filipina memiliki persaingan yang ketat dalam menguasai pangsa pasar (posisi) minyak kelapa impor di pasar internasional. Adapun pangsa (share) impor ketiga negara pengimpor dalam mengekspor minyak kelapa di negara importir utama minyak kelapa dunia (Belanda, USA, dan Jerman), dapat dilihat pada Tabel 1.

Tabel 1 menunjukkan pangsa (share ratarata) impor negara sumber impor minyak kelapa di pasar internasional selama 26 tahun terakhir. Pada Tabel 1 tersebut terlihat bahwa Filipina menempati posisi pertama sebagai negara pengekspor terbesar di pasar Amerika Serikat, Belanda, dan Jerman dengan masingmasing pangsa (share) impor sebesar 77,37 persen, 66,52 persen, dan 40,75 persen. Sementara Indonesia menempati posisi kedua di tiga negara importir tersebut. Pada pasar Amerika, pangsa (share) rata-rata impor minyak kelapa dari Indonesia sebesar 16,70 persen, Belanda sebesar 23,83 persen, dan Jerman sebesar 33,06 persen. Kemudian sisanya impor minyak kelapa diperoleh dari rest of world dengan pangsa impor masingmasingdi negara Amerika Serikat, Belanda, dan Jerman sebesar 6,93; 9,65; dan 26,19

Tabel 1. Pangsa Pasar Negara Sumber Impor Minyak Kelapa di Pasar Internasional

\begin{tabular}{lccc}
\hline \multicolumn{1}{c}{ Negara } & $\begin{array}{c}\text { Pangsa } \\
\text { Impor } \\
\text { Amerika } \\
\text { Serikat }\end{array}$ & $\begin{array}{c}\text { Pangsa } \\
\text { Impor } \\
\text { Belanda }\end{array}$ & $\begin{array}{c}\text { Pangsa } \\
\text { Impor } \\
\text { Jerman }\end{array}$ \\
\hline Filipina & 77,37 & 66,52 & 40,75 \\
$\begin{array}{l}\text { Indonesia } \\
\text { Rest of world }\end{array}$ & 16,70 & 23,83 & 33,06 \\
(ROW) & 5,93 & 9,65 & 26,19 \\
\hline
\end{tabular}

Berdasarkan hasil pangsa (share) yang didapat dari masing-masing negara tersebut menunjukkan bahwa Indonesia masih kalah bersaing dengan Filipina dalam ekspor minyak kelapa di tiga negara pengimpor minyak kelapa dunia tersebut, tetapi Indonesia masih mempunyai peluang cukup besar dalam menguasai pangsa pasar minyak kelapa di Jerman, karena selisih share impor antara Indonesia dan Filipina hanya berkisar 7,69 persen.

\section{ANALISIS FAKTOR-FAKTOR YANG MEMENGARUHI PERMINTAAN IMPOR MINYAK KELAPA INDONESIA DI PASAR INTERNASIOAL}

Dalam penelitian ini, model Almost Ideal Demand System (AIDS) juga digunakan dalam menganalisis faktor-faktor yang memengaruhi permintaan impor minyak kelapa Indonesia di pasar internasional (Amerika Serikat, Belanda, dan Jerman) dengan berdasarkan pada nilai koefisien dan $p$-value dari masingmasing variabel independen untuk mengetahui seberapa besar pengaruh dari variabel tersebut. Adapun variabel dependen dari penelitian ini berupa pangsa (share) impor minyak kelapa Indonesia di masing-masing negara pengimpor. Sedangkan variabel independen yang digunakan berupa harga minyak kelapa Indonesia, harga minyak kelapa Filipina, harga minyak kelapa Malaysia, harga minyak kelapa Rest of World (ROW), total nilai impor pada masing-masing negara pengimpor, nilai tukar, populasi negara pengimpor, pertumbuhan GDP negara pengimpor, harga barang substitusi, harga minyak bumi, dan krisis ekonomi.

Beragam faktor yang secara umum memengaruhi permintaan impor dapat dibedakan menjadi faktor internal dan eksternal (Destiarni, 2016). Beberapa faktor internal yang memengaruhi permintaan impor diantaranya GDP (Jamil, 2015), nilai tukar (Muharami dan Novianti, 2018), populasi (Suherman, 2016). Sementara variabel eksternal berupa harga komoditas impor (Binuomote et al., 2012), harga barang substitusi (Suherman, 2018), dan krisis ekonomi (Rawatie, 2014). Adapun faktorfaktor yang memengaruhi permintaan impor minyak kelapa Indonesia di pasar internasional, akan dibahas berdasarkan masingmasing negara pengimpor yang dapat dilihat pada Tabel 2. 
Tabel 2. Faktor -faktor yang Memengaruhi Permintaan Impor Minyak Kelapa Indonesia di Pasar Amerika Serikat, Belanda, dan Jerman

\begin{tabular}{|c|c|c|c|c|c|c|}
\hline \multirow{2}{*}{ Variabel Independen } & \multicolumn{2}{|c|}{ Amerika Serikat } & \multicolumn{2}{|c|}{ Belanda } & \multicolumn{2}{|c|}{ Jerman } \\
\hline & Koefisien & p-value & Koefisien & p-value & Koefisien & p-value \\
\hline Harga CCO Indonesia (Pind) & $-0,1197$ & 0,350 & 0,3570 & 0,216 & $-0,5462$ & 0,175 \\
\hline Harga CCO Philipina (Pphil) & 0,2174 & 0,104 & $-0,3424$ & 0,243 & 0,3158 & 0,288 \\
\hline Harga CCO rest of world (ROW) & $-0,0977^{*}$ & 0,082 & $-0,0146$ & 0,876 & 0,2304 & 0,303 \\
\hline Total nilai impor $\left(\mathrm{x} / \mathrm{p}^{*}\right)$ & $-0,1479 * *$ & 0,002 & $-0,2581^{* * *}$ & 0,000 & $0,1693^{*}$ & 0,050 \\
\hline Nilai tukar (ER) & $-0,0441^{* *}$ & 0,021 & $-0,0555^{* *}$ & 0,001 & 0,0058 & 0,832 \\
\hline Populasi (POP) & $0,3037^{*}$ & 0,071 & $0,3837^{* *}$ & 0,014 & 0,0646 & 0,185 \\
\hline Produk Domestik Bruto (GDP) & $-0,0063$ & 0,456 & 0,0094 & 0,332 & $-0,0345^{* *}$ & 0,002 \\
\hline Harga Barang Substitusi (PS) & $0,0903^{* *}$ & 0,039 & 0,1074 & 0,235 & $0,2366^{* *}$ & 0,019 \\
\hline Harga minyak bumi (PO) & $-0,0043$ & 0,899 & $0,1735^{\star *}$ & 0,002 & 0,0890 & 0,104 \\
\hline Krisis Ekonomi (D) & $0,1110^{* *}$ & 0,028 & $-0,3019^{* *}$ & 0,003 & $-0,1611^{*}$ & 0,054 \\
\hline Konstanta & 0,8289 & 0,194 & 1,5427 & 0,189 & $-3,5541^{* *}$ & 0,016 \\
\hline \multirow[t]{2}{*}{ Model AIDS Amerika Serikat } & R-Square & $63,43 \%$ & & & & \\
\hline & p-value & 0,0000 & & & & \\
\hline \multirow[t]{2}{*}{ Model AIDS Belanda } & R-Square & $62,16 \%$ & & & & \\
\hline & $\mathrm{p}$-value & 0,0000 & & & & \\
\hline \multirow[t]{2}{*}{ Model AIDS Jerman } & R-Square & $48,54 \%$ & & & & \\
\hline & $\mathrm{p}$-value & 0,0021 & & & & \\
\hline
\end{tabular}

\section{Pasar Amerika Serikat}

Pada pasar Amerika Serikat, terdapat enam variabel independen yang berpengaruh signifikan terhadap permintaan impor minyak kelapa Indonesia di pasar Amerika Serikat. Adapun kelima variabel tersebut yaitu harga minyak kelapa rest of world, total nilai impor, nilai tukar, harga barang substitusi, populasi, dan krisis ekonomi. Sementara terdapat empat variabel yang tidak berpengaruh signifikan pada pangsa (share) impor minyak kelapa Indonesia di pasar Amerika Serikat yaitu harga minyak kelapa Indonesia, harga minyak kelapa Filipina, pertumbuhan GDP, dan harga minyak bumi.

Variabel minyak kelapa rest of world mempunyai pengaruh yang negatif terhadap pangsa (share) impor minyak kelapa Indonesia di pasar Amerika Serikat, sehingga ketika terjadi kenaikan harga minyak kelapa dari rest of world, maka akan menurunkan permintaan minyak kelapa dari Indonesia di pasar Amerika Serikat. Kondisi ini juga diduga terdapat hubungan saling melengkapi (komplementer) antara minyak kelapa dari rest of world dan Indonesia. Dengan demikian, ketika salah satu negara sumber impor menaikkan harga- nya, maka akan menurunkan permintaan komoditi dari negara sumber impor lainnya di negara tujuan ekspor.

Adapun total nilai impor Amerika Serikat juga memberikan korelasi yang negatif terhadap permintaan impor minyak kelapa Indonesia di pasar Amerika Serikat. Kondisi ini diduga karena impor minyak kelapa di pasar Amerika lebih didominasi oleh minyak kelapa yang berasal dari Filipina, sehingga ketika terjadi peningkatan impor minyak kelapa di pasar Amerika, maka Amerika akan lebih meningkatkan impor minyak kelapa yang berasal dari Filipina. Hasil analisis sejalan juga terjadi pada penelitian Suherman (2016), dimana total nilai impor minyak kelapa sawit di Belanda, Spanyol, dan Italia berpengaruh negatif pada permintaan impor minyak kelapa sawit di pasar Belanda, Italia, dan Spanyol, dan hanya berpengaruh positif pada pasar Jerman.

Adapun variabel nilai tukar juga berpengaruh negatif terhadap permintaan impor minyak kelapa Indonesia di pasar Amerika Serikat. Nilai tersebut sesuai dengan hipotesis penelitian, dimana setiap terjadi kenaikan rasio nilai tukar Amerika Serikat atau dengan 
kata lain terjadi depreasi mata uang, maka akan menurunkan permintaan impor minyak kelapa Indonesia di pasar Amerika Serikat. Sementara variabel populasi berpengaruh positif, sehingga ketika terjadi kenaikan populasi Amerika Serikat, maka akan meningkatkan permintaan impor minyak kelapa dari Indonesia.

Berdasarkan hasil estimasi, variabel harga barang substitusi berupa palm kernel oil berpengaruh positif terhadap permintaan impor minyak kelapa Indonesia di pasar Amerika Serikat. Hasil tersebut sesuai dengan hipotesis yang diajukan, dimana ketika terjadi peningkatan harga pada suatu barang, maka akan meningkatkan permintaan barang lain yang mempunyai hubungan saling menggantikan (substitusi).

Variabel krisis ekonomi memiliki pengaruh positif terhadap permintaan minyak kelapa Indonesia di pasar Amerika Serikat. Terjadinya kondisi tersebut diduga karena USA merupakan salah satu negara yang melakukan re-ekspor minyak kelapa. Oleh sebab itu, untuk memenuhi kebutuhan minyak kelapa di tingkat domestik, USA akan tetap melakukan impor meskipun dalam kondisi krisis.

Hal tersebut dibuktikan pada data impor minyak kelapa dari UN Comtrade 2018, dimana sebelum terjadi krisis ekonomi global yang terjadi pada tahun 2008, share impor minyak kelapa dari Indonesia selama periode lima tahun di pasar USA sebesar 0,107 atau setara dengan 10,7 persen. Nilai ini masih lebih rendah dibandingkan pasca terjadinya krisis ekonomi di tahun 2008 yaitu dari tahun 2009-2013, dimana share impor minyak kelapa dari Indonesia sebesar 0,2022 atau 20,22 persen. Dengan demikian, pasca krisis ekonomi global, Amerika Serikat tetap meningkatkan impor minyak kelapa dari Indonesia. Pada penelitian Raswatie (2014) juga ditemukan hasil analisis yang sejalan, dimana variabel dummy krisis ekonomi berpengaruh signifikan dan berkorelasi positif terhadap impor pertanian. Maemunah (2018) dalam penelitiannya juga ditemukan analisis serupa, dimana variabel krisis ekonomi berkorelasi positif terhadap permintaan impor gula dari Thailand.

\section{Pasar Belanda}

Pada pasar Belanda, terdapat lima variabel independen yang berpengaruh signifikan terhadap permintaan impor minyak kelapa Indonesia di pasar Belanda. Variabel-variabel tersebut yaitu total nilai impor pasar Belanda, nilai tukar, populasi, harga minyak bumi, dan krisis ekonomi. Sementara terdapat lima variabel yang tidak signifikan terhadap permintaan minyak kelapa Indonesia di pasar Belanda, seperti harga minyak kelapa Indonesia, harga minyak kelapa Filipina, harga minyak kelapa rest of world, pertumbuhan GDP, dan harga barang substitusi.

Variabel total nilai impor minyak kelapa di pasar Belanda juga memberikan korelasi negatif terhadap permintaan impor minyak kelapa dari Indonesia. Penurunan total nilai impor minyak kelapa Indonesia di pasar Belanda tersebut berdampak lebih besar dibandingkan dengan penurunan total nilai impor minyak kelapa dari Indonesia di pasar Amerika Serikat. Kondisi tersebut diduga karena alokasi impor minyak kelapa di pasar Belanda lebih didominasi dari minyak kelapa dari Filipina.

Adapun pada pasar Belanda, variabel nilai tukar juga menunjukkan korelasi yang negatif terhadap permintaan impor minyak kelapa dari Indonesia. Hasil analisis tersebut sesuai dengan hipotesis penelitian, dimana ketika terjadi rasio kenaikan nilai tukar Belanda atau terjadi depresiasi mata uang, maka barang-barang (minyak kelapa) luar negeri relatif lebih mahal sedangkan barangbarang domestik relatif lebih murah. Oleh karena itu, kondisi tersebut akan menurunkan permintaan impor minyak kelapa Indonesia di pasar Belanda.

Sama halnya dengan pasar Amerika Serikat, di pasar Belanda, populasi juga berpengaruh positif terhadap permintaan minyak kelapa dari Indonesia. Hal ini sesuai dengan hipotesis yang diajukan, dimana ketika terjadi peningkatan populasi Belanda, 
maka akan meningkatkan permintaan impor minyak kelapa dari Indonesia.

Adapun harga minyak bumi mempunyai korelasi yang positif terhadap pemintaan minyak kelapa Indonesia di pasar Belanda, sehingga ketika terjadi peningkatan harga minyak bumi maka akan meningkatkan share (pangsa) impor minyak kelapa dari Indonesia di pasar Belanda. Hasil analisis sejalan juga ditemukan pada penelitian Purba (2012) yang membahas tentang dampak kenaikan harga minyak bumi terhadap permintaan CPO Indonesia di pasar internasional, dimana ketika terjadi kenaikan harga minyak bumi dunia, maka akan mempengaruhi peningkatan permintaan impor CPO Indonesia di pasar internasional.

Sementara variabel krisis ekonomi memberikan dampak yang berbeda dengan pasar Amerika Serikat. Pada pasar Belanda, krisis ekonomi memberikan dampak negatif terhadap permintaan minyak kelapa dari Indonesia. Oleh karena itu, ketika terjadi krisis ekonomi, pasar Belanda akan menurunkan pangsa (share) impor minyak kelapa dari Indonesia di pasar Belanda.

\section{Pasar Jerman}

Pada pasar Jerman, terdapat empat variabel independen yang berpengaruh signifikan terhadap permintaan impor minyak kelapa dari Indonesia di pasar Jerman. Adapun variabel-variabel tersebut yaitu total nilai impor, pertumbuhan GDP, harga barang substitusi, dan krisis ekonomi. Sementara terdapat enam variabel independen yang tidak berpengaruh signifikan terhadap permintaan minyak kelapa Indonesia di pasar Jerman, seperti harga minyak kelapa Indonesia, harga minyak kelapa Filipina, harga minyak kelapa rest of world, nilai tukar, populasi, dan harga minyak bumi.

Berbeda dengan pasar Amerika Serikat dan Belanda, total nilai impor di pasar Jerman mempunyai korelasi yang positif terhadap permintaan impor minyak kelapa Indonesia. Oleh karena itu, ketika terjadi kenaikan impor minyak kelapa di pasar Jerman, maka akan meningkatkan permintaan impor minyak kelapa dari Indonesia.

Adapun variabel pertumbuhan GDP di pasar Jerman berpengaruh negatif terhadap permintaan impor minyak kelapa Indonesia. Hal ini diduga karena perilaku negara Jerman terhadap konsumsi minyak nabati sejenis lainnya. Jerman juga dikenal sebagai negara penghasil berbagai aneka ragam makanan yang menggunakan bahan minyak nabati seperti snack, biskuit, dan cracker. Oleh karena itu, diduga ketika GDP Jerman meningkat atau daya beli masyarakat Jerman meningkat, maka Jerman beralih mengimpor minyak nabati lain sebagai bahan baku industri seperti minyak kedelai dan minyak zaitun. Hasil analisis sejalan juga ditemukan pada penelitian Muslim (2014) yang meneliti tentang faktor-faktor yang memengaruhi nilai impor kedelai di Indonesia, dimana didapatkan korelasi yang negatif antara PDB Indonesia dengan impor kedelai. Korelasi yang negatif ini juga menunjukkan semakin tinggi pendapatan maka preferensi untuk mengkonsumsi kedelai akan berkurang.

Sementara itu, sama dengan pasar Amerika Serikat, variabel harga barang substitusi juga bepengaruh positif terhadap permintaan impor minyak kelapa Indonesia di pasar Jerman. Dengan demikian, ketika terjadi peningkatan harga palm kernel oil, maka akan meningkatkan pangsa pasar minyak kelapa Indonesia di pasar Jerman.

Di pasar Jerman, variabel harga minyak bumi juga berpengaruh positif terhadap permintaan impor minyak kelapa dari Indonesia. Hal ini menunjukkan ketika terjadi peningkatan harga minyak bumi dunia, maka akan meningkatkan absorpsi minyak kelapa dari Indonesia di pasar Jerman.

Sama halnya dengan Belanda, variabel krisis ekonomi di pasar Jerman juga berpengaruh negatif terhadap pangsa (share) impor minyak kelapa dari Indonesia di pasar Jerman. Oleh karena itu, ketika terjadi krisis ekonomi, maka Jerman cenderung mengurangi impor minyak kelapa dari Indonesia. 


\section{ANALISIS TINGKAT PERSAINGAN MINYAK KELAPA INDONESIA DI PASAR INTERNASIONAL}

Model Almost Ideal Demand System (AIDS) yang digunakan dalam penelitian ini juga merupakan sebuah fungsi permintaan yang menggambarkan persaingan antara Indonesia dan Filipina sebagai negara sumber impor minyak kelapa dunia di pasar internasional (Amerika Serikat, Belanda, dan Jerman). Dari hasil analisis model AIDS, dapat diketahui nilai elastisitas dari masing-masing negara sumber impor pada pasar internasional. Nilai elastisitas yang didapat berupa elastisitas harga sendiri, elastisitas harga silang, dan elastisitas pengeluaran. Nilai elastisitas tersebut dapat digunakan untuk melihat tingkat persaingan minyak kelapa Indonesia dengan negara pesaing Indonesia. Selain itu, nilai elastisitas dapat dijadikan informasi penting bagi pelaku ekonomi, baik produsen, konsumen, maupun pemerintah dalam mengambil keputusan. Pada dasarnya dari fungsi permintaan dapat diperoleh gambaran mengenai bagaimana pengaruh perubahan-perubahan kondisi ekonomi (harga dan pendapatan) terhadap kuantitas permintaan (Virgantari, 2012), namun dalam praktiknya seringkali informasi tersebut tidak cukup hanya sekedar mengetahui apakah permintaan tersebut naik atau turun. Oleh karena itu, diperlukan pengukuran elastisitas untuk mengetahui ukuran kepekaan kuantitas terhadap berbabagi faktor tersebut. Perhitungan ketiga elastisitas pada negara sumber impor akan dibahas pada masingmasing negara pengimpor.

\section{Pasar Amerika Serikat}

Amerika Serikat adalah salah satu negara pengimpor minyak kelapa terbesar di dunia. Amerika Serikat masih menempati peringkat pertama sebagai pengimpor minyak kelapa dunia. Minyak kelapa yang diimpor oleh Amerika Serikat sebagian besar berasal dari Indonesia dan Filipina, dimana total share impor minyak kelapa dari kedua negara tersebut mencapai 94,07 persen. Berdasarkan hasil estimasi model AIDS, dapat diketahui nilai elastisitas harga sendiri, elastisitas harga silang, dan elastisitas pengeluaran di pasar Amerika Serikat yang dapat dilihat pada Tabel 3.

Tabel 3. Nilai Elastisitas Minyak Kelapa Indonesia dan Filipina di Pasar Amerika Serikat

\begin{tabular}{lccc}
\hline \multirow{2}{*}{ Elastisitas } & \multicolumn{3}{c}{ Negara } \\
\cline { 2 - 4 } & Indonesia & Filipina & $\begin{array}{c}\text { Rest of } \\
\text { World }\end{array}$ \\
\hline $\begin{array}{l}\text { Harga } \\
\text { Indonesia }\end{array}$ & $-1,56898$ & 1,98704 & $-0,53237$ \\
$\begin{array}{l}\text { Harga } \\
\text { Filipina }\end{array}$ & 0,2535 & $-1,53058$ & 0,11256 \\
Pengeluaran & 0,11430 & 0,59674 & - \\
\hline
\end{tabular}

Pada Tabel 3 terlihat bahwa nilai elastisitas harga sendiri yang didapat pada masing-masing negara sumber impor bernilai negatif. Hal tersebut diharapkan karena menggambarkan slope yang negatif dari kurva permintaan. Norton et al. (2010) juga menegaskan bahwa pada umumnya nilai elastisitas harga sendiri bernilai negatif. Nilai elastisitas harga sendiri minyak kelapa dari Indonesia sebesar -1,56898 dan Filipina sebesar -1,53058.

Sementara nilai elastisitas pengeluaran yang didapat pada kedua negara sumber impor bernilai positif. Adapun nilai elastisitas pengeluaran untuk minyak kelapa dari Indonesia sebesar 0,11430 dan Filipina sebesar 0,59674. Nilai elastisitas pengeluaran pada minyak kelapa dari Indonesia dan Filipina mencerminkan nilai elastisitas pengeluaran yang inelastis karena nilai mutlaknya kurang dari 1, namun untuk besaran nilainya Filipina lebih besar dari Indonesia. Oleh karena itu, di pasar Amerika Serikat, Filipina akan lebih diuntungkan karena nilai elastisitas pengeluarannya lebih besar dibandingkan dengan Indonesia. Dengan demikian, ketika terjadi peningkatan permintaan impor minyak kelapa di pasar Amerika Serikat, maka permintaan minyak kelapa dari Filipina akan meningkat lebih besar dibandingkan dengan Indonesia. 
Pada Tabel 3 juga terdapat informasi nilai elastisitas harga silang pada negara sumber impor minyak kelapa di pasar Amerika Serikat. Elastisitas harga silang tersebut menggambarkan persentase perubahan jumlah barang yang dikonsumsi karena adanya perubahan harga dari komoditas lain yang saling berkaitan. Melalui elastisitas harga silang, dapat dilihat sifat suatu barang apakah barang tersebut merupakan barang substitusi atau barang komplementer. Berdasarkan hasil estimasi dengan model AIDS, diketahui bahwa nilai elastisitas silang antara Indonesia dengan Filipina bertanda positif, sementara antara Indonesia dengan minyak kelapa dari rest of world bertanda negatif. Dengan demikian, terdapat hubungan saling menggantikan pada minyak kelapa dari Indonesia dengan Filipina, dan saling melengkapi antara minyak kelapa dari Indonesia dengan rest of world. Nilai elastisitas silang yang bertanda positif mencerminkan hubungan yang saling bersubstitusi diantara negara sumber impor, sehingga menunjukkan adanya persaingan antar negara eksportir dalam menguasai pasar tujuan (Destiarni, 2016). Sedangkan nilai elastisitas silang yang bertanda negatif menunjukkan bahwa barang tersebut berbeda dan saling melengkapi atau dapat dikatakan kedua barang tersebut memiliki sifat komplementer (Medelin, 2011). Dengan demikian, Indonesia mendapat persaingan yang ketat dengan Filipina sebagai pemasok minyak kelapa di pasar Amerika Serikat.

\section{Pasar Belanda}

Belanda merupakan salah satu negara importir minyak kelapa di dunia. Belanda sendiri menempati urutan kedua sebagai pengimpor minyak kelapa terbesar didunia dan pengimpor minyak kelapa terbesar di Eropa. Adapun minyak kelapa yang diimpor oleh Belanda sebagain besar berasal dari Indonesia dan Filipina dengan pangsa impor (share) impor keduanya mencapai 90,35 persen. Tabel 4 menunjukkan nilai elastisitas harga sendiri, elastisitas pengeluaran, dan elastisitas harga silang pada minyak kelapa dari Indonesia dan Filipina di pasar Belanda.

Tabel 4. Nilai Elastisitas Minyak Kelapa Indonesia dan Filipina di Pasar Belanda

\begin{tabular}{lccc}
\hline \multirow{2}{*}{ Elastisitas } & \multicolumn{3}{c}{ Negara } \\
\cline { 2 - 4 } & Indonesia & Filipina & Malaysia \\
\hline Harga & & & \\
Indonesia & 0,75632 & $-0,71645$ & 0,04331 \\
Harga & & & \\
Filipina & $-0,59532$ & $-0,90634$ & 0,16379 \\
Pengeluaran & $-0,8318$ & 1,3184 & - \\
\hline
\end{tabular}

Pada Tabel 4, diketahui bahwa nilai elastisitas harga sendiri pada Indonesia dan Filipina masing-masing sebesar 0,75632 dan -0.9634. Nilai elastisitas harga sendiri pada minyak kelapa dari Indonesia bertanda positif. Hal tersebut tidak sesuai dengan teori permintaan, dimana seharusnya ketika terjadi peningkatan harga suatu barang, maka seharusnya menurunkan permintaan dari barang tersebut. Kondisi tersebut diduga karena Belanda tidak hanya menjadi pengimpor minyak kelapa, melainkan Belanda juga termasuk negara yang mengekspor minyak kelapa ke negara Uni Eropa lainnya.

Oleh karena itu, Belanda akan tetap melakukan impor minyak kelapa dari Indonesia untuk memenuhi kebutuhan minyak kelapa dalam negeri, meskipun harga minyak kelapa Indonesia cenderung meningkat. Pada penelitian Sukmaya (2017), Belanda menjadi salah satu negara eksportir minyak kelapa dunia yang juga menempati posisi lima besar eksportir minyak kelapa dunia. Selain itu, diduga pula kualitas minyak kelapa Indonesia turut memengarui permintaan minyak kelapa dari Indonesia di pasar Belanda. Dengan demikian, Belanda akan tetap melakukan impor meskipun harga minyak kelapa Indonesia cenderung meningkat. Hasil analisis sejalan juga ditemukan pada penelitian Jamil (2015) dan Muslim (2014). Pada penelitian Jamil (2015), ditemukan nilai elastisitas harga sendiri pada garam impor India bertanda positif. Muslim (2014) dalam penelitiannya, ditemukan bahwa bahwa pada dasarnya 
Indonesia merupakan negara pengimpor kedelai. Oleh karena itu, meskipun harga kedelai impor meningkat, Indonesia akan tetap melakukan impor.

Berbeda dengan pasar Amerika Serikat, di pasar Belanda, nilai elastisitas pengeluaran dari minyak kelapa Indonesia bertanda negatif yaitu $-0,8318$. Hal ini menunjukkan bahwa ketika terjadi pengeluaran pada Belanda, maka akan menurunkan permintaan minyak kelapa dari Indonesia. Sebaliknya, pada minyak kelapa dari Fiipina, nilai elastisitas pengeluarannya bertanda positif sebesar 1,3184. Nilai tersebut juga menunjukkan bahwa di pasar Belanda, Filipina akan lebih diuntungkan dibandingkan dengan Indonesia. Semakin tinggi total impor minyak kelapa di Belanda, maka semakin besar pangsa impor minyak kelapa dari Filipina

Tabel 4 juga memberikan informasi mengenai nilai elastisitas harga silang diantara kedua negara sumber impor minyak kelapa di pasar Belanda. Adapun nilai elastisitas silang antara Indonesia dengan Filipina memiliki tanda yang negatif, sementara antara Indonesia dengan minyak kelapa rest of world memiliki tanda yang positif. Tanda negatif pada elastisitas silang menunjukkan hubungan saling melengkapi (komplementer), sementara tanda positif menunjukkan hubungan saling menggantikan (substitusi). Dengan demikian, dapat dikatakan bahwa di pasar Belanda, minyak kelapa dari Indonesia tidak bersaing dengan Filipina, melainkan bersaing degan minyak kelapa dari rest of world.

\section{Pasar Jerman}

Saat ini Jerman menempati posisi ketiga sebagai negara pengimpor minyak kelapa di dunia. Sama seperti pasar Amerika Serikat dan Belanda, sebagaian besar impor minyak kelapa Jerman didapatkan dari Indonesia dan Filipina, dimana share impor minyak dari Indonesia sebesar 33,06 persen dan dari Filipina sebesar 40,75 persen.

Tabel 5 menunjukkan hasil nilai elastisitas harga sendiri, elastisitas pengeluaran, dan elastisitas harga silang pada masing-masing negara sumber impor minyak kelapa di pasar Jerman.

Tabel 5. Nilai Elastisitas Minyak Kelapa Indonesia dan Filipina di Pasar Jerman

\begin{tabular}{lccc}
\hline \multirow{2}{*}{ Elastisitas } & \multicolumn{3}{c}{ Negara } \\
\cline { 2 - 4 } & Indonesia & Filipina & Malaysia \\
\hline Harga & & & \\
Indonesia & $-2,82132$ & 0,74656 & 0,56260 \\
Harga & & & \\
Filipina & 0,84327 & $-2,11584$ & 0,47900 \\
Pengeluaran & 1,51216 & $-0,19996$ & - \\
\hline
\end{tabular}

Nilai elastisitas harga sendiri pada negara sumber impor di pasar Jerman masingmasing memiliki tanda yang negatif. Artinya, setiap terjadi kenaikan harga minyak kelapa sebesar 1 persen dari negara sumber impor, maka akan menurunkan permintaan impor minyak kelapa dari negara sumber impor tersebut sebesar nilai elastisitas yang didapat di pasar Jerman. Hasil analisis tersebut telah sesuai dengan teori permintaan, dimana ketika terjadi peningkatan harga suatu barang, maka akan menurunkan permintaan akan barang tersebut. Nilai elastisitas harga sendiri yang didapat pada Indonesia dan Filipina menunjukkan elastisitas harga sendiri yang elastis, karena nilai mutlaknya lebih dari 1. Nilai ini juga menunjukkan bahwa baik Indonesia dan Filipina, keduanya sensitif terhadap perubahan harga.

Adapun nilai elastisitas pengeluaran pada minyak kelapa dari Indonesia bernilai positif yaitu 1,51216, sedangkan elastisitas minyak kelapa dari Filipina bernilai negatif yaitu sebesar -0,19996. Nilai elastisitas pengeluaran yang positif pada minyak kelapa dari Indonesia menunjukkan ketika terjadi peningkatan pengeluaran impor pada pasar Jerman, maka akan meningkatkan pangsa (share) impor minyak kelapa dari Indonesia. Sedangkan nilai elastisitas pengeluaran yang negatif pada Filipina menunjukkan bahwa ketika terjadi peningkatan permintaan impor minyak kelapa, maka akan menurunkan pangsa (share) impor minyak kelapa dari Filipina. 
Dengan demikian, dapat dikatakan bahwa berdasarkan nilai elastistas pengeluaran tersebut, Indonesia akan lebih diuntungkan karena memiliki nilai elastisitas pengeluaran yang elastis. Oleh karena itu, ketika terjadi peningkatan pengeluaran impor minyak kelapa di pasar Jerman, maka pangsa (share) impor minyak kelapa dari Indonesia akan meningkat lebih besar dibandingkan dengan Filipina.

Berdasarkan Tabel 5 dapat diketahui pula nilai elastisitas silang diantara negara sumber impor. Hubungan saling menggantikan (substitusi) terdapat pada negara Indonesia dengan Filipina serta Indonesia dengan rest of world, sehigga dapat diartikan ketika terjadi kenaikan harga minyak kelapa di salah satu negara sumber impor, maka akan meningkatkan pangsa impor minyak kelapa dari negara sumber impor lainnya yang berhubungan saling menggantikan. Hubungan substitusi yang terjadi pada komoditi impor dari dua negara tertentu menunjukkan bahwa kedua komoditi dari kedua negara tersebut sama dan saling menggantikan, sehingga ketika suatu negara tidak mampu memasok minyak kelapa dalam jumlah yang cukup, maka Jerman mempunyai alternatif lain untuk mendapatkan minyak kelapa impor dari negara lain karena sifatnya yang sama. Hubungan substitusi ini juga menunjukkan adanya persaingan antar negara sumber impor dalam menguasai pangsa pasar pada negara tujuan ekspor. Dengan demikian, dapat dikatakan bahwa di pasar Jerman, Indonesia bersaing ketat dengan Filipina maupun dengan minyak kelapa dari rest of world untuk menguasai pangsa impor minyak kelapa di pasar Jerman.

\section{KESIMPULAN DAN SARAN}

\section{KESIMPULAN}

Hasil penelitian menunjukkan bahwa faktor-faktor yang memengaruhi permintaan impor minyak kelapa dari Indonesia di pasar internasional berbeda-beda. Pada pasar Amerika Serikat, variabel yang berpengaruh sig- nifikan berupa harga minyak kelapa rest of world, total nilai impor, nilai tukar, populasi, harga barang substitusi dan krisis ekonomi. Pada pasar Belanda terdapat lima variabel yang berpengaruh signifikan yaitu total nilai impor, nilai tukar, populasi, harga minyak bumi, dan krisis ekonomi. Sementara pada pasar Jerman terdapat empat variabel yang berpengaruh signifikan yaitu total nilai impor, harga barang substitusi dan krisis ekonomi. Pada analisis persaingan, didapatkan bahwa hasil minyak kelapa Indonesia bersaing di ketiga negara pengimpor minyak kelapa. Di pasar Amerika Serikat, Indonesia bersaing dengan Filipina dan di pasar Belanda, Indonesia bersaing dengan minyak kelapa dari rest of world. Sementara di pasar Jerman, Indonesia bersaing dengan minyak kelapa dari Filipina maupun rest of world. Adapun persaingan tersebut ditunjukkan dengan nilai elastisitas silang yang positif (substitusi).

\section{SARAN}

Adanya persaingan diantara negara sumber impor dalam menguasai pangsa pasar minyak kelapa di pasar internasional, maka pemerintah diharapkan dapat mengambil kebijakan yang dapat mendorong peningkatan ekspor minyak kelapa Indoneia. Salah satu kebijakan yang dapat dilakukan adalah dengan meningkatkan produksi kelapa Indonesia secara kualitas dan kuantitas yang dapat dilakukan dengan pemberian subsidi maupun dalam bentuk riset untuk komoditi kelapa. Selain itu, pemerintah juga perlu memperhatikan peluang yang telah didapat pada masing-masing negara pengimpor untuk memenangkan persaingan dalam menguasai pangsa ekspor minyak kelapa di pasar internasional, seperti adanya nilai elastisitas pengeluaran Indonesia yang bernilai positif di pasar Amerika maupun Jerman. Nilai tersebut menunjukkan bahwa adanya peningkatan pengeluaran pada negara pengimpor, maka akan turut meningkatkan pangsa (share) impor minyak kelapa dari Indonesia. Hal tersebut dapat dimanfaatkan sebagai peluang dan strategi pemasaran mi- 
nyak kelapa Indonesia di pasar internasional, dimana Indonesia dapat meningkatkan pasokan ekspor minyak kelapa ke pasar Amerika Serikat dan pasar Jerman

\section{DAFTAR PUSTAKA}

Allorerung D, Mahmud Z, Novarianto H, Luntungan H. 2005. Prospek dan Arah Pengembangan Agribisnis Kelapa. Badan Penelitian dan Pengembangan Pertanian, Departemen Pertanian.

Anajohn J. 2018. Developments in World Trade With Crude Coconut Oil [tesis]. Bogor : Institut Pertanian Bogor.

Arimbawa P, Zani M. 2013. Analisis Usaha Pembuatan Minyak Kelapa Sekala Rumah Tangga Kelompok Tani di Desa Peoho, Kecamatan Watu Bangga, Kabupaten Kolaka. Jurnal Agriplus 3: 2431.

Aulia AN. 2017. Volatilitas dan Daya Saing Minyak Kelapa Indonesia [tesis]. Yogyakarta (ID) : Universitas Gadjah Mada

Binuomote SO, Odeniyi KA, Farayola CO. 2012. Econometric Estimation of Rice Import Demand in Nigeria (1970-2008): An Application of Autoregressive Distributed Lags (ARDL) Modelling Approach to Cointegration. Continental J. Agricultural Economics. 6 (12) : 1-8

Chang HS, Nguyen C. 2002. Elasticity of Demand for Australian Cotton in Japan. The Australian Journal of Agriculture and Resource Economics. 46(1): 99-113.

Deaton A, Muellbauer J. 1980. An Almost Ideal Demand System. The American Economic Review. 70(3): 312-326.

Destiarni RP. 2016. Analisis Permintaan Daging Sapi Impor Indonesia [tesis]. Bogor : Institut Pertanian Bogor.

[FAO] Food Agricultural Organization. 2017. FAO Agricultural Trade Information and Statistics Service. FAOSTAT-Universal Software for Trade Statistical Time Series
[Internet]. [diunduh 2018 Oktober 28]. Tersedia pada: http:// http://www.fao.org/faostat/en/\#data /QD

[FAO] Food Agricultural Organization. 2018. FAO Agricultural Trade Information and Statistics Service. [Internet]. [diunduh 2018 Oktober 30]. Tersedia pada : http: http://www.fao.org/faostat/en/\#ranki ngs/countries_by_commodity

Jamil AS. 2015. Analisis Permintaan Impor Garam Indonesia [tesis]. Bogor (ID) : Institut Pertanian Bogor.

Jiumpanyarach W. 2011. Estimation of demand system in an AIDS model: The Opportunity of Exporting Thai Agricultural Products. European Journal of Business and Economics. 5: 63-67.

Jung J, Koo WW. 2000. An Econometric Analysis of Demand for Meat and Fish Products in Korea. Agricultural Economics Report No. 439. North Dakota State University, North Dakota.

Kahar M. 2010. Analisis Pola Konsumsi Daerah Perkotaan dan Perdesaan Serta Keterkaitannya dengan Karakteristik Sosial Ekonomi di Provinsi Banten [tesis]. Bogor (ID): Institut Pertanian Bogor

Maemunah A. 2018. Pola Permintaan Impor Raw Sugar di Kawasan ASEAN dan Non ASEAN [tesis]. Bogor : Institut Pertanian Bogor.

Medelin J. 2001. Caribbean Demand of US and Rest of the World Starchy Food (Wheat, Rice, Corn and Fresh Potatoes): A Restricted Source Differentiated Almost Ideal Demand System. Lecturas de Economia. No 55

Muslim A. 2014. Faktor-faktor yang Memengaruhi Nilai Impor Kedelai Indonesia. Buletin Ilmiah Litbang Perdagangan. 8(1):117-138.

Norton GW, Alwang J, Masters WA. 2010. Economics of Agricultural Development. New York (US): Routledge. 
Prihandana R, Hendroko R. 2008. Energi Hijau. Jakarta (ID) : Penebar Swadaya.

Purba S. 2012. Dampak Kenaikan Harga Minyak Bumi Terhadap Permintaan CPO untuk Biodisel dan Beberapa Aspek Pada Indusrti Kelapa Sawit Indonesia. Jurnal Ilmiah Ranggagading. 12 (2) : 176-185.

Rachmi DM, Nurmalina R, Rifin A. 2017. Competition Analysis of Imported and Local Oranges. Jurnal Manajemen $\mathcal{E}$ Agribisnis. 15 (1) : 1-11

Raswati. 2014. Hubungan Ekspor-Impor Produk Domestik Bruto (PDB) di Sektor Pertanian Indonesia. Journal of Agriculture, Resource, and Enviromental Economic. 1(1):28-42

Rifin A. 2013. Competitiveness of Indonesia's Cocoa Beans Export in the World Market, International Journal of Trade, Economics and Finance. 4(5): 279 - 281.

Suherman T. 2016. Analisis Permintaan Impor Minyak Kelapa Sawit Indonesia di Eropa 4 [tesis]. Bogor (ID): Institut Pertanian Bogor

Sukmaya SG. 2017. Analisis Permintaan Minyak Kelapa Indonesia di Pasar Internasional. AGRARIS: Journal of Agribusiness and Rural Development Research.3(1): 1 - 8 .

Setyawan S, Purwanti E. 2016. Nilai Tambah dan Profitabilitas Komoditas Kelapa di Kabupaten Natuna. Riset Akuntansi Keuangan. 1(1): 75-84.

[UNCOMTRADE] United Commodity Trade Database. 2018. [Internet]. [diunduh 2018 November 1]. Tersedia pada : http://comtrade.un.org/data.

[USDA] United States Department of Agriculture. 2016. Oilseeds: World markets and trade. [Internet]. [diakses 2018 Oktober 30]. Tersedia pada : https://apps.fas.usda.gov/psdonline/ci rculars/oilseeds.pdf.

Virgantari F. 2012. Analisis permintaan produk perikanan di indonesia: suatu studi cross-sectional [disertasi]. Bogor (ID): Institut Pertanian Bogor. 